Article

\title{
Effects of Various Drying Methods on Selected Physical and Antioxidant Properties of Extracts from Moringa oliefera Leaf Waste
}

\author{
Ade Chandra Iwansyah ${ }^{1}{ }^{\mathbb{D}}$, Tran Dinh Manh ${ }^{2, *}$, Yusuf Andriana ${ }^{1}{ }^{\mathbb{D}}$, \\ Muhammad Aiman bin Hessan ${ }^{3}$, Faridah Kormin ${ }^{3}$, Dang Xuan Cuong ${ }^{4}{ }^{\oplus}$, Nguyen Xuan Hoan ${ }^{5}$, \\ Hoang Thai Ha ${ }^{5}$, Dang Thi Yen ${ }^{5}$, Pham Van Thinh ${ }^{5}$, Lam The Hai ${ }^{5}$ and Truong Ngoc Minh ${ }^{6, *(\mathbb{B})}$ \\ 1 Research Center for Appropriate Technology, Indonesian Institute of Sciences, Subang 41213, Indonesia; \\ chandra.iwansyah@gmail.com (A.C.I.); yusuf.andriana@lipi.go.id (Y.A.) \\ 2 Institute of Research and Development, Duy Tan University, Da Nang 550000, Vietnam \\ 3 Department of Technology and Natural Resources, Faculty of Applied Science and Technology University \\ Tun Hussein Onn Malaysia, Pagoh 86400, Malaysia; muhdaimanhesan@gmail.com (M.A.b.H.); \\ faridahk@uthm.edu.my (F.K.) \\ 4 NhaTrang Institute of Technology Application and Research, VAST, Khanhhoa 650000, Vietnam; \\ biofoodchemtech@gmail.com \\ 5 Faculty of Environment-Natural Resources and Climate Change, Ho Chi Minh University of Food Industry, \\ Ho Chi Minh 700000, Vietnam; hoannx@hufi.edu.vn (N.X.H.); hoangha.hufi@gmail.com (H.T.H.); \\ yendt@hufi.edu.vn (D.T.Y.); thinhpv@hufi.edu.vn (P.V.T.); hailt@cntp.edu.vn (L.T.H.) \\ 6 Vietnam Academy of Science and Technology (VAST), Center for Research and Technology \\ Transfer (CRETECH), 18 Hoang Quoc Viet Road, Hanoi 100000, Vietnam \\ * Correspondence: trandinhmanh@duytan.edu.vn (T.D.M.); anphuminh1011@gmail.com (T.N.M.); \\ Tel.: +84-987-367-311 (T.D.M.); +84-4-3756-8422 (T.N.M.)
}

Received: 17 August 2020; Accepted: 5 October 2020; Published: 16 October 2020

\begin{abstract}
This study aims to evaluate the effects of different drying methods on the physical properties, total phenolic content, total flavonoid content, and antioxidant activity of extracts from Moringa oliefera $\mathrm{L}$. (MO) leaf waste. The effects of two drying techniques, namely, sun drying (A1) and tray drying (A2), on the physical and antioxidant properties of the extracts obtained using three extracting solvents, i.e., water (b1), ethanol (b2), and ethyl acetate (b3), were investigated. These extracts were analyzed for their physicochemical and antioxidant properties. The antioxidant properties were determined with the Folin Ciocalteau, aluminum chloride, and 1,1-diphenyl-2-picrylhydrazyl (DPPH) assays. Fourier transform infrared spectrophotometry (FTIR) was used to identify functional groups in the active compounds. It was found that the physical properties of the $\mathrm{MO}$ extract, including yield, $\mathrm{pH}$, total solids, and color, showed significant differences for the two drying methods $(p<0.05)$. The b3 extract had the highest value for total phenolic contents, total flavonoid contents, and antioxidant activities, followed by $\mathrm{b} 2$ and b1, respectively, for both the sun drying and tray drying methods. There was a significant correlation between the total phenolic and flavonoid contents and antioxidant activity ( $\mathrm{IC}_{50}$ ). This study reveals that waste material from MO leaves could be utilized as an antioxidant agent, which is expected to reduce environmental pollution from the MO processing industry.
\end{abstract}

Keywords: antioxidant properties; Moringa oleifera; physicochemical properties; tray drying

\section{Introduction}

Plants are among the sources of medicinal treatments for health and prevention of diseases [1]. According to the World Health Organization (WHO), 80\% of the world's population primarily depends 
on classic remedies, such as plants and herbs, for medicinal treatment [2]. The therapeutic functions of plants are due to the presence of a range of phytochemicals and their elemental compositions. Medicinal plants can be used to treat a broad spectrum of diseases, such as bacterial infections, inflammatory diseases, oxidative stress, etc. Such properties among plants are usually attributable to the presence of a wide range of amphipathic molecules, commonly known as polyphenolic compounds [3].

There is an increasing trend in both the study and development of medicinal plants as natural sources of antioxidants in the food and healthcare industries. Traditionally, parts of plants, such as leaves, fruits, and flowers, are edible; thus, they are widely consumed in many nations [4-6]. Although not every part of every plant has healing properties, each plant part has therapeutic potential which can be explored as a possible source of compounds of interest to the pharmaceutical industry [1,7]. Among herbs with potential therapeutic effects is Moringa oleifera, also known as Moringa or Kelor (Indonesian).

Moringa oleifera (MO) is commonly used as a food supplement to combat malnourishment, particularly for infants and nursing mothers in developing countries [8]. Additionally, the aerial parts of MO are used as a traditional herbal medication to treat numerous disorders and diseases, such as skin infection, respiratory sickness, and ear and dental infections [9]. Generally, antioxidants play a role in maintaining the physiological functions of the liver, kidneys, and digestive system. They can also prevent cardiovascular disease and cancer in humans [10]. According to Kumar et al. [11], some epidemiological studies have reported the benefits of flavonoids, which act as antioxidants in humans and have functions such as immunomodulation, improved cognitive function, and risk reduction of certain cancers, cardiovascular diseases, and skin diseases. Flavonoids have antioxidative, anti-inflammatory, antimutagenic, and anticarcinogenic properties, coupled with a capacity to modulate key cellular enzyme functions. Flavonoids have been reported to prevent coronary heart disease in humans [12].

Many studies have reported that plant extracts of MO possess broad therapeutic potential, e.g., antioxidant [13,14], antihyperlipidaemic, and hypoglycemic effects [15]. Furthermore, the potential ability of MO extracts to prevent the formation of cyclophosphamide-induced micronucleus and DNA damage in mice specimens has been shown [16]. As stated by Fakurazi et al. [17], an aqueous extract of $\mathrm{MO}$ improves the restoration of hepatic glutathione. Additionally, it has been reported that $\mathrm{MO}$ can prevent azoxymethane-induced colon carcinogenesis [18]. Ingesting the powder made from the plant leaves also improves brain function and cognitive alertness, and plays a crucial role in memory, mood elevation, organ function, and stimulus response [19]. It has been reported that crude ethanol MO extract possesses antidepressant properties [20]. MO has been found to contain polyphenol and antioxidant compounds [21]. However, in processing MO, there are off-grade leaves that cannot be further processed due their quality; these leaves might possess phenolic and flavonoid substances [22]. The leaves also possess trace elements that are vital to human health, such as magnesium, iron, selenium, and zinc, all of which play a crucial role in metabolism. Research interest in these elements is increasing, with many reports appearing recently on trace element status and oxidative diseases $[23,24]$. According to Valdez-solana et al. [1], the mineral and phenolic contents present in leaves depend on several factors, such as the plants' geographical area, type of soil, water, fertilizers, industrialization process, and storage conditions.

The most important step in extracting useful bioactive compounds from waste MO leaves is the drying process. Drying processes are commonly utilized for the structural preservation of fruits and plants, but they may cause discoloration, loss of aroma, and changes of texture and physical properties. Drying at higher temperatures reduces the drying duration, but results in a poor-quality product compared with drying for a more extended period at a lower temperature [25]. Numerous studies have been conducted on drying processes of several leaves and vegetables such as eggplant [26], red pepper [27], and black tea [28]. However, the drying behavior of off-grade MO leaves is largely unreported in the literature, with the exception of one report on convective drying [29] and another 
on the drying behavior of MO leaves at different temperatures [25]. Using this waste material is expected to reduce pollution in the MO industry.

Additionally, the extraction process is a critical step in isolating bioactive compounds from plant matrices. Many factors affect the efficacy of bioactive compound extraction, such as temperature and the choice of solvent. Generally, most antioxidant compounds such as phenolics and flavonoids are dissolved in ethyl acetate $[30,31]$. This solvent is moderately polar, with polarity index of 4.4, i.e., lower than that of water (9.0) but higher than those of chloroform (4.1) and hexane (0) [32].

In Europe, MO leaf powder-based products appear mostly in the cosmetic market and in food supplements [33]. In Indonesia, consumers prefer to buy fresh MO leaves, which should be consumed within one day after harvesting. However, a lack of efficient logistic systems makes fresh MO leaves scarce in the marketplace. To address this problem, MO leaves may be dried, thereby extending their shelf-life. After harvesting, fresh MO leaves may be processed into powder by washing, drying in sunlight and pulverizing them into a fine powder. The coarse material left over in the blending (rotary blade chopping) process is usually disposed of, generating significant waste [34]. This study aims to evaluate the effects of three different drying methods on the physical properties, total phenolic contents, total flavonoid contents, and antioxidant activity of extracts from MO leaf waste. It is expected that this study will provide information about the possibility of using waste from $\mathrm{MO}$ as an antioxidant source.

\section{Materials and Methods}

\subsection{Plant Materials and Reagents}

MO leaf waste of was collected from Pondok Bitung Cooperation, Bogor, Indonesia from September to December, 2019. The collected material comprised leaves that could not be further processed into MO leaf powder products due to their off-grade quality. The MO leaves had, for the most part, been harvested 6 months before acquisition. Quercetin, aluminum chloride, gallic acid, ethanol, ethyl acetate, n-hexane, sodium hydroxide, sodium carbonate, Folin-Ciocalteu's phenol, 1,1-dipheynyl 2-picrylhydrazyl (DPPH) were obtained from Sigma-Aldrich Pte Ltd., Singapore. All reagents used were analytical grade.

\subsection{Preparation of Samples}

The MO leaf waste from three separate batches was collected in a cool box and stored at $4{ }^{\circ} \mathrm{C}$ until further processing. The samples were then washed and dried using two drying methods, i.e., sun drying (A1) or tray drying (A2). In the sun drying method, the MO leaf waste was put on a tray and dried directly in sunlight for $4 \mathrm{~h}$. For tray drying, the MO leaf waste was put in a tray and dried in a cabinet dryer at $45^{\circ} \mathrm{C}$ for $4 \mathrm{~h}$. The dried MO leaves were then pulverized into powder using a disk mill. A volume of $50 \mathrm{~g}$ of the dried powder was then soaked in distilled water (b1), ethyl acetate (b3), or 96\% ethanol $(\mathrm{b} 2)(500 \mathrm{~mL})$ at a ratio of 1:10 $(\mathrm{w} / \mathrm{v})$ for $24 \mathrm{~h}$ by maceration methods (three times, from three batches of samples). After that, the filtrate was concentrated, weighed, and dried at $50{ }^{\circ} \mathrm{C}$ with a rotary evaporator (Rotavapor R-300 Buchi, Flawil, Switzerland). The dry crude extracts were stored in an air-tight container and kept in a refrigerator $\left(4^{\circ} \mathrm{C}\right)$ until further analysis [35].

\subsection{Determination of Physical Properties of MO Leaf Waste Powder}

Physical properties viz., $\mathrm{pH}$, total solids, total acids, and color were analyzed following methods reported previously [36].

\subsection{Determination of Total Phenolic Contents (TPC)}

The TPC of MO leaf waste extract were determined using a Folin-Ciocalteu assay with a minor modification [35]. Briefly, $10 \mathrm{mg}$ of the dry crude extract was placed in a centrifuge tube and $10 \mathrm{~mL}$ of distilled water or ethanol was added. The samples were shaken for $30 \mathrm{~min}$, and then centrifuged at $5000 \mathrm{rpm}$ for $20 \mathrm{~min}$. The extract, blank, or gallic acid standard solution with different concentrations 
$(0.1 \mathrm{~mL})$ was mixed with distilled water $(2.8 \mathrm{~mL})$ and sodium carbonate $(2 \%, 2 \mathrm{~mL})$, and pre-incubated for $4 \mathrm{~min}$. Then, Folin-Ciocalteu $(100 \mu \mathrm{L})$ was added to the solution and incubated for $30 \mathrm{~min}$ in ambient conditions. The measurement of the sample was conducted at $\lambda=760 \mathrm{~nm}$ against the blank using a spectrophotometer (SHIMADZU UV-1900, Tokyo, Japan). TPC were calculated based on a standard curve obtained by measuring several concentrations of gallic acid standard. The TPC of samples were expressed as $\mathrm{mg}$ gallic acid equivalent (GAE) in $\mathrm{g}$ of dry weight. Samples were analyzed in triplicate and presented as means \pm standard deviation.

\subsection{Determination of Total Flavonoid Contents (TFC)}

The TFC of the MO leaf waste extracts were determined by using the aluminum chloride assay, as reported previously [37]. Briefly, a volume of $1 \mathrm{~mL}$ extract, blank, or standard solution of quercetin $\left(0-200 \mu \mathrm{g} \mathrm{mL}^{-1}\right)$ was mixed with aluminum chloride solution $(2 \%, 2 \mathrm{~mL})$. The mixture was then shaken thoroughly and incubated at room temperature for $30 \mathrm{~min}$. Measurement against the blank was carried out using a spectrophotometer (SHIMADZU UV-1900, Tokyo, Japan) at wavelength $(\lambda)=415 \mathrm{~nm}$. The TFC were calculated according to the equation and expressed in mg quercetin equivalent (QE) per gram dry weight of plant extract.

\subsection{The 1,1-Dipheynyl 2-Picrylhydrazyl (DPPH) Assay}

The antiradical activity of the MO leaf waste extracts was measured using 1,1-dipheynyl 2-picrylhydrazyl (DPPH), as reported previously, with a slight modification [35]. To the extract, blank, or standard solution $(1 \mathrm{~mL})$, a volume of $3 \mathrm{~mL}$ DPPH solution $(0.004 \%)$ was added. The reaction mixture was then incubated at room temperature for $30 \mathrm{~min}$ in dark conditions. The measurement against the blank was carried out using a spectrophotometer (SHIMADZU UV-1900, Tokyo, Japan) at wavelength $(\lambda)=517 \mathrm{~nm}$. Data were expressed as the concentration of antiradical activity required for $50 \%$ scavenging of DPPH radicals in the specified time period $\left(\mathrm{IC}_{50}\right)$. Samples were analyzed in triplicate.

\subsection{Fourier Transform Infrared Spectrophotometry (FTIR)}

Dried powder of the MO leaf waste extracts was used for FTIR analysis. The samples were loaded into an FTIR spectroscope (Bruker A7.8) with a scan range from 450 to $4000 \mathrm{~cm}^{-1}$.

\subsection{Statistical Analysis}

The data were presented in means \pm standard deviations (SD). Significant differences in the data were determined by Duncan's test $(\alpha=5 \%)$. A statistical analysis was performed in a randomized factorial design by one-way analysis of variance (ANOVA) using Minitab ${ }^{\circledR} 16.2 .3$ (copyright $@ 2020$ Minitab Inc., Philadelphia, PA, USA) to determine the effects of different solvents. Meanwhile, significant differences in the drying method data were determined by the Independent Sample $t$-test $(\alpha=5 \%)$. Correlation analyses between TPC, TFC, and antioxidant activity using Pearson's correlation were also performed.

\section{Results}

\subsection{Physicochemical Properties}

\subsubsection{Yield and Color}

The total yields of MO leaf waste extracts using different solvents and drying methods are shown in Figure 1. The ethanolic extract showed the highest yield for both sun and tray drying methods, with values of $50.87 \%$ and $71.07 \%$, respectively, followed by water and ethyl acetate extracts $(p<0.05)$. All extracts obtained from the extracting solvents were observed as dark brown or greenish semisolids. 


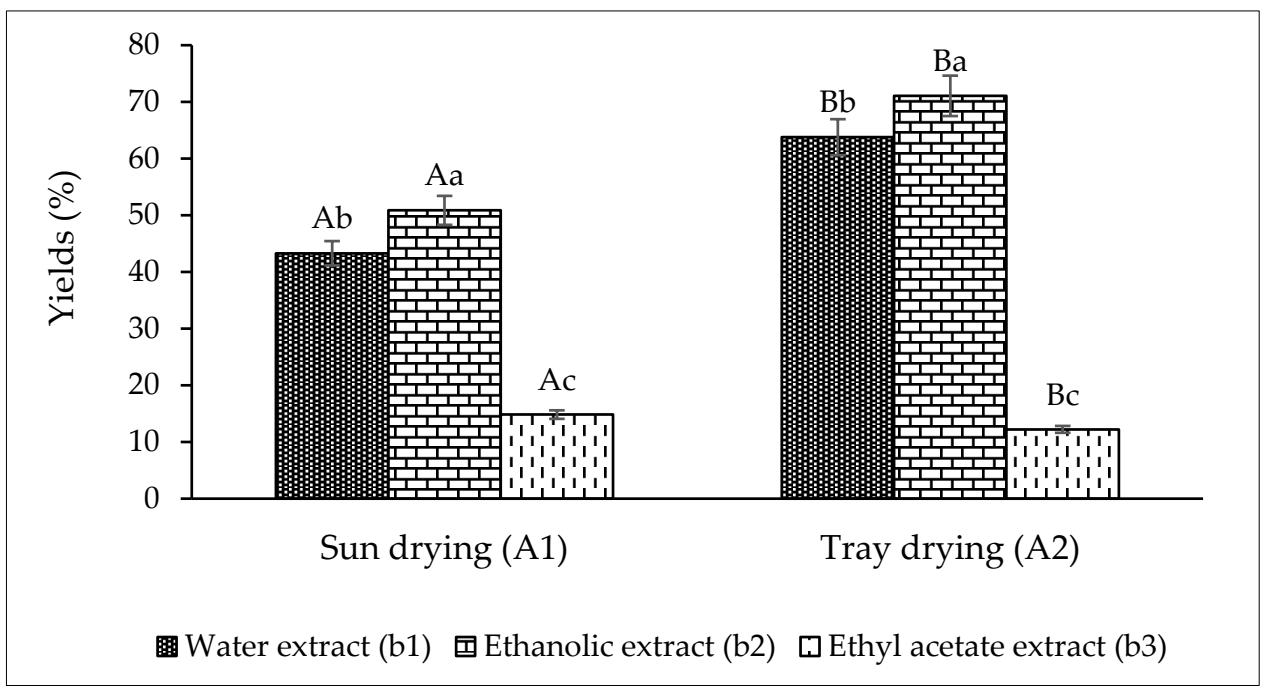

Figure 1. Yields of M. oleifera extract. Data are presented as mean \pm standard deviation $(n=3)$. Values followed different upper-case letters above the same colored bars (i.e., for the same solvent), or different lower-case letters (i.e., for the same drying method) are significantly different according to the Duncan's test $(p<0.05)$.

The results of color analyses of the MO leaf waste powder are shown in Table 1. The results show that most parameters observed, i.e., $L^{*}, a^{*}$, and $b^{*}$ values, were significantly different with different drying methods. $L^{*}$ represents a dark powder, while $a^{*}$ and $b^{*}$ represent reddish and yellowish colors, respectively. Meanwhile, for Hue, the differences between the two drying methods were negligible. This indicates that the drying method affected the color of the waste MO leaf powder $(p<0.05)$.

Table 1. Color analyses of MO leaf powder.

\begin{tabular}{ccc}
\hline Color Parameters & Tray Drying & Sun Drying \\
\hline$L^{*}$ & $48.040 \pm 0.210^{a}$ & $51.055 \pm 0.118^{b}$ \\
$a^{*}$ & $-3.390 \pm 0.040^{a}$ & $-0.536 \pm 0.086^{b}$ \\
$b^{*}$ & $11.580 \pm 0.150^{a}$ & $15.500 \pm 0.080^{b}$ \\
Hue & $+0.003 \pm 0.002^{a}$ & $+0.002 \pm 0.001^{a}$ \\
\hline
\end{tabular}

Data are presented as mean \pm standard deviation (SD) $(n=3)$. Values followed different small letters in the same row are significantly different according to an independent sample t-test $(p<0.05) . L^{*}=$ the lightness value $\left(L^{*}=0\right.$ means the darkest black, $L^{*}=100$ means the brightest white). $a^{*}=$ from green $(-)$ to red $(+) . b^{*}=$ from blue $(-)$ to yellow $(+)$. Hue $=$ color appearance parameter.

\subsection{2. $\mathrm{pH}$, Total Dissolved Solids, and Total Acidity}

Table 2 shows the $\mathrm{pH}$, total dissolved solids, and total acidity of MO leaf waste dried with different drying methods. For the $\mathrm{pH}$ values, the results show that the extracts were significantly affected by the drying process $(p<0.05)$, ranging from 4.98 to 6.82. Similarly, in the total acidity assay, the drying process affected the total acidity of the samples $(p>0.05)$, with values ranging from 0.0015 to $0.0029 \%$. Additionally, the drying process affected the total solids $(p<0.05)$, with values ranging from 0.13 to $22.33^{\circ}$ Brix. The sun drier (A1) yielded higher values of total solids in comparison with extracts made using the tray drier (A2). Regarding the extracting solvent used, ethyl acetate extract showed the highest total solids for both drying methods $(p<0.05)$. 
Table 2. $\mathrm{pH}$, total solids, and total acidity of the extracts from $\mathrm{MO}$ leaf waste.

\begin{tabular}{cccc}
\hline Samples & $\mathbf{p H}$ & Total Solid ( ${ }^{\circ}$ Brix) & Titration Acid (\%) \\
\hline \multicolumn{4}{c}{ Sun drier $(A 1)$} \\
\hline Water extract (b1) & $5.95 \pm 0.01^{A b}$ & $0.77 \pm 0.06^{A b}$ & $0.0017 \pm 0.0001$ \\
Ethanolic extract (b2) & $6.82 \pm 0.01^{A a}$ & $0.37 \pm 0.06^{A c}$ & $0.0029 \pm 0.0001$ \\
Ethyl acetate extract (b3) & $4.91 \pm 0.06^{A c}$ & $22.33 \pm 0.49^{A a}$ & $0.0018 \pm 0.0002$ \\
\multicolumn{4}{c}{ Tray drier $(A 2)$} \\
Water extract (b1) & $5.62 \pm 0.00^{B b}$ & $1.40 \pm 0.10^{B b}$ & $0.0015 \pm 0.0001$ \\
Ethanolic extract (b2) & $6.36 \pm 0.02^{B a}$ & $0.13 \pm 0.06^{B c}$ & $0.0018 \pm 0.0002$ \\
Ethyl acetate extract (b3) & $4.98 \pm 0.08^{B c}$ & $21.63 \pm 0.15^{B a}$ & $0.0017 \pm 0.0002$ \\
\hline
\end{tabular}

Data are presented as mean \pm standard deviation (SD). Values with different letters in the same column are significantly different according to the Duncan's test $(p<0.05)$. Values followed different upper-case letters in the same row (i.e., for the same solvent), or different lower-case letters in the same column (i.e., for the same drying method) are significantly different according to the Duncan's test $(p<0.05)$.

\subsection{Antioxidant Activity}

The antioxidant activity of the extracts from the MO leaf waste are shown in Figure 2. The results show that the drying method significantly affected the antioxidant properties of the samples $(p<0.05)$. Furthermore, the ethyl acetate extract of MO (b3) showed the highest antiradical activities, followed by ethanolic extract $>$ water extract, for both drying methods $(p<0.05)$.

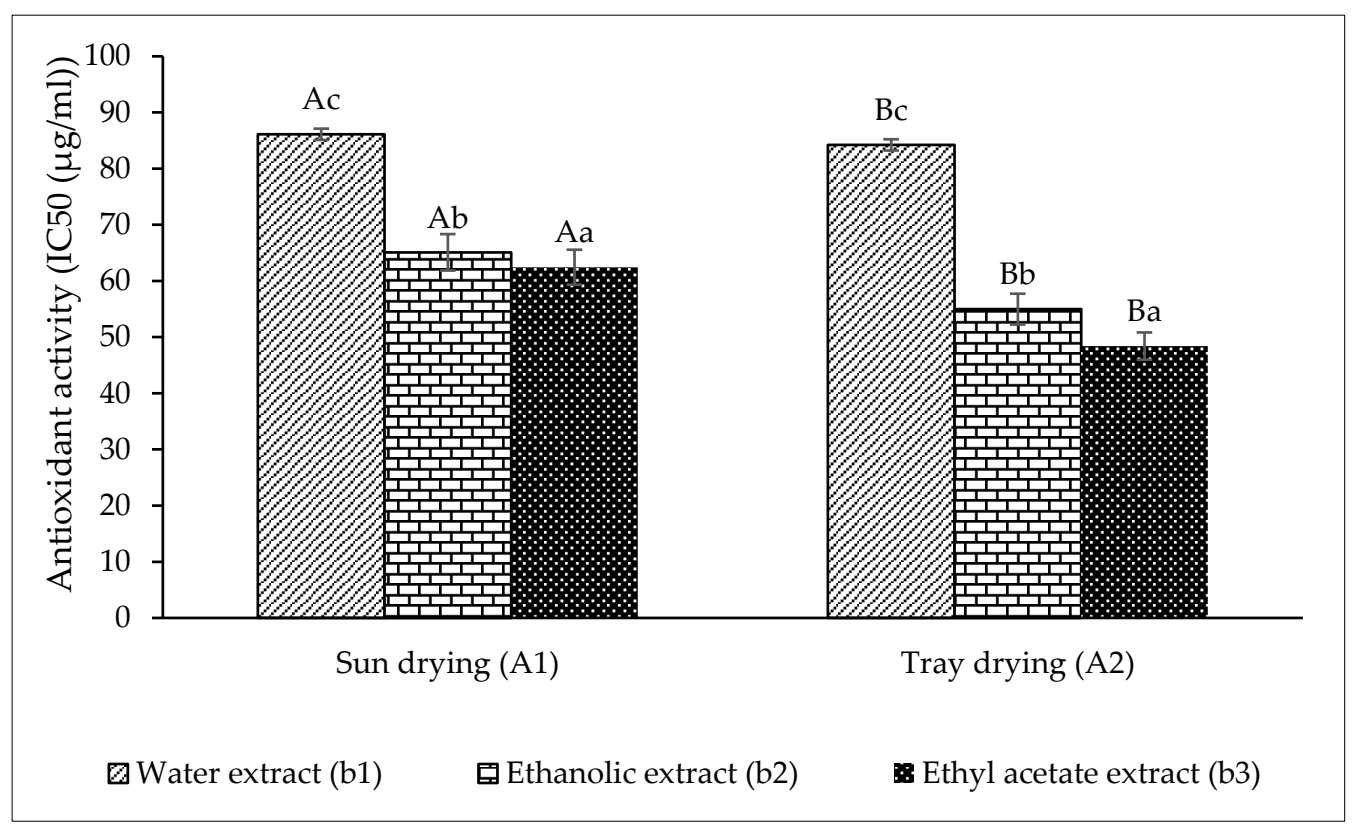

Figure 2. Antioxidant activity of MO extract. Data are presented as mean \pm standard deviation $(n=3)$. Values followed different upper-case letters above the same colored bars (i.e., for the same solvent), or different lower-case letters (i.e., for the same drying method) are significantly different according to the Duncan's test $(p<0.05)$.

\subsection{Total Phenolic and Flavonoid Contents}

The TPC of the extracts of MO leaf waste are shown in Table 3. The results show that the samples were significantly affected by the drying process. The ethyl acetate extract (b3) exhibited the highest value of TPC, followed by ethanol and water extracts, for both drying methods $(p<0.05)$. 
Table 3. Total phenolics content of M. oleifera leaf extracts.

\begin{tabular}{ccc}
\hline \multirow{2}{*}{ Samples } & \multicolumn{2}{c}{ mg GAE/100 g } \\
\cline { 2 - 3 } & Sun Drying (A1) & Tray Drying (A2) \\
\hline Water extract (b1) & $9.64 \pm 0.85^{A c}$ & $9.19 \pm 0.42^{B c}$ \\
Ethanolic extract (b2) & $11.15 \pm 0.68^{A b}$ & $12.38 \pm 0.92^{B b}$ \\
Ethyl acetate extract (b3) & $11.87 \pm 0.55^{A a}$ & $13.63 \pm 0.71^{B a}$ \\
\hline
\end{tabular}

Data are presented as means \pm standard deviations (SD). GAE = gallic acid equivalent. Values followed different upper-case letters in the same row (i.e., for the same solvent), or different lower-case letters in the same column (i.e., for the same drying method) are significantly different according to the Duncan's test $(p<0.05)$.

\subsection{Total Flavonoid Contents}

The TFC of the extracts of MO leaf waste are shown in Table 4. The data show that the TFC were significantly affected by the drying process $(p<0.05)$. The ethyl acetate extract (b3), for both drying processes, possessed the highest TFC, followed by ethanolic extract $>$ water extract $(p<0.05)$.

Table 4. Total flavonoids content of M. oleifera leaves extract.

\begin{tabular}{ccc}
\hline \multirow{2}{*}{ Samples } & \multicolumn{2}{c}{ mg QE/100 g } \\
\cline { 2 - 3 } & Sun Drier (A1) & Tray Drier (A2) \\
\hline Water extract (b1) & $3.63 \pm 0.51^{\mathrm{Ac}}$ & $2.53 \pm 0.23^{\mathrm{Bc}}$ \\
Ethanolic extract (b2) & $20.09 \pm 1.17^{\mathrm{Ab}}$ & $9.85 \pm 0.39^{\mathrm{Bb}}$ \\
Ethyl acetate extract (b3) & $27.75 \pm 0.53^{\mathrm{Aa}}$ & $31.22 \pm 0.23^{\mathrm{Ba}}$ \\
\hline
\end{tabular}

Data are presented as means \pm standard deviations $(\mathrm{SD})$. $\mathrm{QE}=$ quercetin equivalent. Values followed different upper-case letters in the same row (i.e., for the same solvent), or different lower-case letters in the same column (i.e., for the same drying method) are significantly different according to the Duncan's test $(p<0.05)$.

\subsection{Identification of Active Functional Groups}

The results of an FTIR analysis of extracts of MO leaf waste are shown in Figure 3. Peaks were observed at $2916.41 \mathrm{~cm}^{-1}$ and $2916.25 \mathrm{~cm}^{-1}$, and at 1633.37 and $1614.49 \mathrm{~cm}^{-1}$.

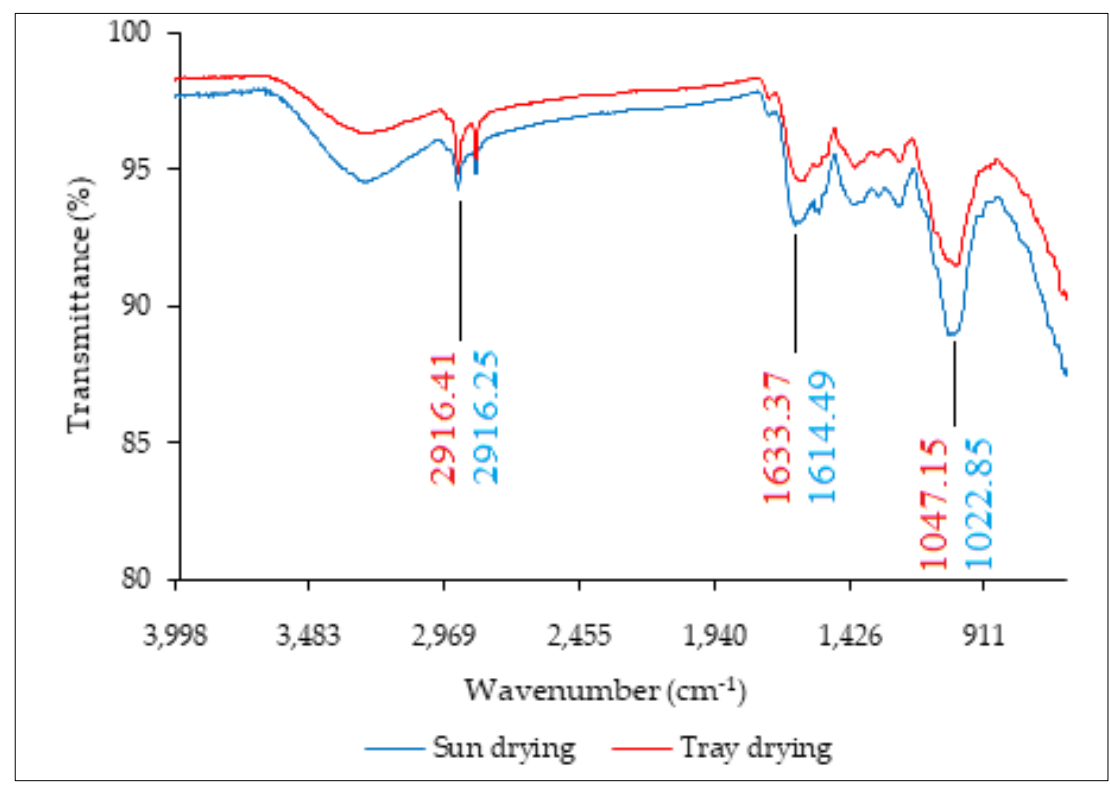

Figure 3. FTIR analysis of M. oleifera leaves. 


\subsection{Correlation of TPC, TFC, and Antiradical Activity}

The antioxidant activities of plant extracts can be related to their phenolic and flavonoid contents. There was a significant correlation between TPC and TFC, for both sun drying and tray drying, with Pearson's correlation coefficients of $r=-0.926$ and $r=-0.744$, respectively (Table 5).

Table 5. Correlation of TPC, TFC, and antioxidant activity.

\begin{tabular}{|c|c|c|c|}
\hline Parameters & TPC & TFC & Antioxidant Activity $\left(\mathrm{IC}_{50}\right)$ \\
\hline TPC & 1 & $0.753^{* *}$ & $-0.926^{* *}$ \\
\hline TFC & & 1 & $-0.744^{* *}$ \\
\hline Antioxidant activity $\left(\mathrm{IC}_{50}\right)$ & & & 1 \\
\hline
\end{tabular}

Analysis revealed that there was a significant negative correlation between antioxidant activity $\left(\mathrm{IC}_{50}\right)$ to TPC and TFC. This is indicative of the presence of large amounts of TPC or TFC, i.e., free radical scavengers, in the samples. The TPC and TFC contents in the samples were proportional to their antioxidant activity (low $\mathrm{IC}_{50}$ value).

\section{Discussion}

This study assessed the possible use of off-grade Moringa olifera (MO) leaves as food ingredients by analyses of their physical and antioxidant properties. Physical properties are important, as they are associated with food characteristics. The extraction processes applied in this study to leaves from the same sample, and the use of different drying methods, yielded extracts in amorphous form and dark brown to greenish in color. Similar cases have been reported by Adeoye et al. [38]. Parts of the plant, including leaf, stem, and root, contain numerous solute molecules with more than one functional group. Thus, it is difficult to theorize about the solubility and interactions of the solute in a specific solvent. The extraction yields were affected by many factors, notably, the polarity of the solvent. Polarity describes a molecule's ability to partake in strong interactions with other polar molecules, not specifically in the presence of a molecule of a large dipole moment [38]; relative polarity is therefore the sum of all possible interactions [39].

In a color analysis, most parameters, i.e., $L^{*}, a^{*}$, and $b^{*}$, for leaves dried by solar drying showed higher values than those dried in a tray dryer. The chlorophyll content of the leaves can influence their brightness, i.e., a darker color could be interpreted as indicative of a higher the chlorophyll content. This red $a^{*}$ value can indicate the presence of alkaloid and phenol compounds, both of which have orange, red, brownish-red and brown pigments [40]. A yellow color can indicate the presence of flavonoid compounds [41]. The MO leaf waste was generally yellow in color, suggesting the presence of active flavonoid compounds with yellow, orange to orange pigments [42].

The high yields from the ethanol and water extractions indicated that these solvents have high affinity and solubility with the MO leaf waste. Given the presence of hydroxyl groups, which are hydrophilic, the molecules in these extracts dissolve more efficiently in these solvents. A similar observation was made by Kumoro et al. [39], where the extract yields from MO plants decreased with decreasing solvent polarity. Therefore, lower polar solvents such as, in this case, ethyl acetate, were not able to significantly extract the MO.

The parameters of $\mathrm{pH}$, total dissolved solids, and total acidity of the extracts varied slightly according to the drying method. For extraction using ethanol (b2), for both drying methods, the product showed a higher $\mathrm{pH}$ value compared to those extracted using water or ethyl acetate. A previous report by Mechlouch et al. [43] stated that the drying process caused significant variations in the $\mathrm{pH}$ values of dried tomatoes. Different drying methods such as solar drying, air drying, and microwave drying with variations electricity powers and temperatures were applied to evaluate their effects to $\mathrm{pH}$ values of dried tomatoes. The results showed that tomatoes dried using a microwave $\left(3 \mathrm{~W} \mathrm{~g}^{-1}, 57^{\circ} \mathrm{C}\right)$ gave the minimum $\mathrm{pH}$ value compared to other drying methods. In another study by the same authors [44], 
the $\mathrm{pH}$ values for palm date exhibited a decrement according to the drying method; the fresh date sample had a $\mathrm{pH}$ value of 6.63 , while dried samples had $\mathrm{pH}$ values ranging from 5.91, after direct solar drying, to 4.51 , after microwave drying $\left(3 \mathrm{~W} \mathrm{~g}^{-1}, 100^{\circ} \mathrm{C}\right)$. Meanwhile, for total dissolved solids, the results of the present study are in agreement with those Mechlouch et al. [43], who conducted a Brix analysis of tomatoes which had been dried using direct solar and microwave drying $\left(3 \mathrm{~W} \mathrm{~g}{ }^{-1}\right.$, $57^{\circ} \mathrm{C}$ ); the results showed that microwave drying was more effective than drying in sunlight.

Regarding antioxidant parameter, ethyl acetate was shown to be the most effective extracting solvent in terms of enhancing the quantity of DPPH free radicals. This result is in agreement with that of Shanmugavel et al. [45], who reported that MO ethyl acetate and ethanolic extracts had the highest antioxidant activities, i.e., $\beta$-carotene-linoleic acid systems at $65.1 \%$ and $66.8 \%$, respectively, compared with the water extract. A similar study by Vongsak et al. [36] measured antioxidant activity using various extraction approaches of Thai MO leaves; those authors obtained similar results, i.e., the extract obtained from macerated dried leaves with 70\% ethanol revealed high DPPH-scavenging activity, with $\mathrm{IC}_{50}$ of $62.94 \mathrm{~g} \mathrm{~mL}^{-1}$, and the highest FRAP value: $51.50 \mathrm{mmol} \mathrm{FeSO}_{4}$ equivalent $100 \mathrm{~g}^{-1}$ extract. The leaves of $\mathrm{MO}$ are a plentiful source of antioxidant compounds. Numerous reports can be found in the literature regarding the antioxidant properties and activities of MO leaves $[46,47]$.

Flavonoids are a subgroup of polyphenolic compounds having a benzo- $\gamma$-pyrone structural composition, and are abundant in plants, where they are produced in response to microbial infections. This study revealed that off-grade MO leaf extracts contain significant levels of phenolic and flavonoid compounds. This result is in agreement with Kumar and Pandey [48], who reported on the phenolic content of four selected Indian medicinal plants (Camellia sinensis, Sesbania grandiflora, Thespesia populnea, Cassia auriculata).

It is difficult to attribute the antioxidant activity to any specific component present in the extracts, since a complex mixture of chemical compounds is present. Generally, phenolic compounds exhibit the greatest antioxidant activity [49]. According to Iwansyah et al. [35], the scavenging effect of extracts is not limited to their phenolic contents, but may also due be to the presence of other antioxidants, for example, secondary metabolites such as volatile oils, carotenoids, and vitamins. The process of drying can degrade the cellular constituents within plant samples, which leads to the accelerated release of phenolic compounds [50]. According to Leone et al. [51], the dried leaves of MO contain large amounts of polyphenols, i.e., primarily flavonoids and phenolic acids. The extraction method may have been the cause for such a wide range of reported values of these compounds.

From functional group analysis by FTIR, our results had similar peaks to those reported by Bello et al. [52], i.e., at both $1623 \mathrm{~cm}^{-1}$ and $1012 \mathrm{~cm}^{-1}$. The FTIR spectra revealed that the peaks moved to some extent with different drying techniques; this was probably due to temperature differences in the drying process. More specifically, shifts in peak values were largely due to chemical bonds being formed between the functional groups present in MO; similar observations were reported in [53]. A similar peak was reported by Shanmugavel et al. [45] at $2931.66 \mathrm{~cm}^{-1}$, which indicates the presence of an alkane group (C-H). In contrast, the peaks at around $1633.37 \mathrm{~cm}^{-1}$ and $1614.49 \mathrm{~cm}^{-1}$ correspond to $\mathrm{C}=\mathrm{O}$ stretch. The peaks observed at $1047.15 \mathrm{~cm}^{-1}$ and $1022.85 \mathrm{~cm}^{-1}$ correspond to $\mathrm{C}=\mathrm{O}$ bonds of ether, ester, or phenol.

\section{Conclusions}

In this study, the possible use of Moringa oleifera leaf waste as a source of antioxidants was examined. Two drying processes, i.e., sun drying and tray drying, and three solvent extracts, i.e., water, ethanol, and ethyl acetate, were tested; these parameters were shown to have a significant impact on the physical and antioxidant properties of the samples. Ethyl acetate was found to be most effective for the extraction of antioxidant agents from moringa waste. Compared to sun drying, tray drying produced a better quality dried extract, i.e., with higher total phenolic contents, total flavonoids contents, and free-radical scavenging capability. The stability of the temperature in the dryer may 
affect the quality of the dried extract. The use of waste from this plant is expected to reduce pollution, e.g., by minimizing the dumping of moringa waste, and to provide a new source of antioxidant agents.

Author Contributions: A.C.I. and Y.A. conceptualized, implemented the research, and wrote the manuscript. M.A.b.H., N.X.H., D.X.C., H.T.H., and D.T.Y. wrote the first draft. F.K., P.V.T., and L.T.H. revised and gave advice to improve the research. T.N.M. and T.D.M. conceptualized and revised the paper. All authors have read and agreed to the published version of the manuscript.

Funding: This research is funded by Vietnam National Foundation for Science and Technology Development (NAFOSTED) under grant number 104.01-2019.316.

Acknowledgments: The authors are grateful to the Indonesian Institute of Sciences (LIPI) for the financial assistance of global research collaboration initiation (B-1423/SU/KP.06.01/XI/2019), LPDP RISPRO Mandatory 2020, and Universiti Tun Hussein Onn (UTHM) for providing access and technical support, as well as Raden Cecep Erwan Andriansyah who had helped this research.

Conflicts of Interest: The authors declare no conflict of interest.

\section{References}

1. Valdez-Solana, M.A.; Mejía-García, V.Y.; Téllez-Valencia, A.; García-Arenas, G.; Salas-Pacheco, J.M.; Alba-Romero, J.J.; Campos, E.S. Nutritional Content and Elemental and Phytochemical Analyses of Moringa oleifera Grown in Mexico. J. Chem. 2015, 2015, 1-9. [CrossRef]

2. Eekor, M. The Growing use of Herbal Medicines: Issues Relating to Adverse Reactions and Challenges in Monitoring Safety. Front. Pharmacol. 2014, 4, 177. [CrossRef]

3. Demiray, S.; Pintado, M.E.; Castro, P.M.L. Evaluation of Phenolic Profiles and Antioxidant Activities of Turkish Medicinal Plants: Tilia Argentea, Crataegi Folium Leaves and Polygonum Bistorta Roots. Int. J. Med. Health Biomed. Bioeng. Pharm. Eng. 2009, 3, 74-79. [CrossRef]

4. Anhwange, B.A.; Ajibola, V.O.; Oniye, S.J. Chemical Studies of the Seeds of Moringa oleifera (Lam) and Detarium microcarpum (Guill and Sperr). J. Bio. Sci. 2004, 4, 711-715. [CrossRef]

5. Anwar, F.; Ashraf, M.; Iqbal, M. Interprovenance Variation in the Composition of Moringa oleifera Oilseeds from Pakistan. J. Am. Oil Chem. Soc. 2005, 82, 45-51. [CrossRef]

6. Oluduro, A.O. Evaluation of Antimicrobial Properties and Nutritional Potentials of Moringa oleifera Lam. Leaf in South-Western Nigeria. Malays. J. Microbiol. 2012, 8, 59-67. [CrossRef]

7. Njan, A.A.; Amali, M.O.; Olatunji, L.O.; Olorundare, O.E. An Overview of the Ethno-Pharmacological Potentials of Moringa Oleifera Lam, "The Miracle Tree". Arch. Basic App. Med. 2014, 2, 135-145.

8. Dhakar, P.R.C.; Pooniya, B.; Gupta, M. Moringa: The Herbal Gold to Combat Malnutrition. Chron. Young Sci. 2011, 2, 119. [CrossRef]

9. Ogbunugafo, H.; Eneh, F.; Ozumba, A.; Igwo-Ezikp, M.; Okpuzor, J.; Igwilo, I.; Adenekan, S.; Onyekwelu, O. Physico-chemical and Antioxidant Properties of Moringa oleifera Seed Oil. Pak. J. Nutr. 2011, 10, 409-414. [CrossRef]

10. Wilson, D.; Nash, P.; Buttar, H.S.; Griffiths, K.; Singh, R.; De Meester, F.; Horiuchi, R.; Takahahi, T. The Role of Food Antioxidants, Benefits of Functional Foods, and Influence of Feeding Habits on the Health of the Older Person: An Overview. Antioxidants 2017, 6, 81. [CrossRef]

11. Kumar, R.M.; Kavitha, K.; Dhanaraj, S.A. Role of Flavonoids in Human Nutrition as Health Promoting Natural Chemical-A Review. J. Appl. Pharm. 2014, 6, 228-234.

12. Panche, A.N.; Diwan, A.D.; Chandra, S.R. Flavonoids: An overview. J. Nutr. Sci. 2016, 5, e47. [CrossRef]

13. Charoensin, S. Antioxidant and Anticancer Activities of Moringa Oleifera Leaves. J. Med. Plant Res. 2014, 8, 318-325. [CrossRef]

14. Gupta, R.; Kannan, G.M.; Sharma, M.; Flora, S. Therapeutic Effects of Moringa oleifera on Arsenic-induced Toxicity in Rats. Environ. Toxicol. Pharmacol. 2005, 20, 456-464. [CrossRef] [PubMed]

15. Yadav, J.; Satish, K.S.; Lalit, S. Evaluation of Antidepressant Activity of Leaves Extract of Moringa oliefera by Using FST and TST Model on Swiss Albino Mice. World J. Pharm. Res. 2016, 5, 967-976. [CrossRef]

16. Sathya, T.N.; Aadarsh, P.; Deepa, V.; Murthy, B.P. Moringa oleifera Lam. Leaves Prevent Cyclophosphamide-Induced Micronucleus and DNA Damage in Mice. Int. J. Phytomed. 2010, 2, 147-154. [CrossRef] 
17. Fakurazi, S.; Hairuszah, I.; Nanthini, U. Moringa oleifera Lam Prevents Acetaminophen Induced Liver Injury through Restoration of Glutathione Level. Food Chem. Toxicol. 2008, 46, 2611-2615. [CrossRef]

18. Budda, S.; Butryee, C.; Tuntipopipat, S.; Rungsipipat, A.; Wangnaithum, S.; Lee, J.-S.; Kupradinun, P. Suppressive Effects of Moringa oleifera Lam Pod Against Mouse Colon Carcinogenesis Induced by Azoxymethane and Dextran Sodium Sulfate. Asian Pac. J. Cancer Prev. 2011, 12, 3221-3228.

19. Yunusa, S.; Aliyu, M. Ethyl-Acetate and Aqueous Fractions of Moringa Oleifera Lam (Moringaceae) Leaf Extract Possess Antidepressant Activity in Mice. Afr. J. Pharm. Ther. 2018, 7, 1-6.

20. Kaur, G.; Invally, M.; Sanzagiri, R.; Buttar, H.S. Evaluation of the Antidepressant Activity of Moringa oleifera Alone and in Combination with Fluoxetine. J. Ayurveda Integr. Med. 2015, 6, 273-279. [CrossRef]

21. Mishra, G.; Singh, P.; Verma, R.; Kumar, S.; Srivastav, S.; Jha, K.K.; Khosa, R.L. Traditional Uses, Phytochemistry and Pharmacological Properties of Moringa Oleifera Plant: An Overview. Der Pharm. Lett. 2011, 3, 141-164.

22. Mbikay, M. Therapeutic Potential of Moringa oleifera Leaves in Chronic Hyperglycemia and Dyslipidemia: A Review. Front. Pharmacol. 2012, 3, 1-12. [CrossRef]

23. Cajuday, L.A.; Glorina, L.P. Effects of Moringa oleifera Lam. (Moringaceae) on the Reproduction of Male Mice (Mus Musculus). J. Med. Plants Res. 2010, 4, 1115-1121. [CrossRef]

24. Shazia, Q.; Mohammad, Z.H.; Rahman, T.; Shekhar, H.U. Correlation of Oxidative Stress with Serum Trace Element Levels and Antioxidant Enzyme Status in Beta Thalassemia Major Patients: A Review of the Literature. Anemia 2012, 2012, 1-7. [CrossRef]

25. Meda, A.; Lamien, C.E.; Romito, M.; Millogo, J.; Nacoulma, O.G. Determination of the Total Phenolic, Flavonoid and Proline Contents in Burkina Fasan Honey, as well as their Radical Scavenging Activity. Food Chem. 2005, 91, 571-577. [CrossRef]

26. Ali, M.; Yusof, Y.; Chin, N.L.; Ibrahim, M.; Basra, S. Drying Kinetics and Colour Analysis of Moringa Oleifera Leaves. Agric. Agric. Sci. Procedia 2014, 2, 394-400. [CrossRef]

27. Ertekin, C.; Yaldiz, O. Drying of Eggplant and Selection of a Suitable Thin Layer Drying Model. J. Food Eng. 2004, 63, 349-359. [CrossRef]

28. Doymaz, I.; Pala, M. Hot-air Drying Characteristics of Red Pepper. J. Food Eng. 2002, 55, 331-335. [CrossRef]

29. Panchariya, P.; Popovic, D.; Sharma, A. Thin-layer Modelling of Black Tea Drying Process. J. Food Eng. 2002, 52, 349-357. [CrossRef]

30. Andriana, Y.; Xuan, T.D.; Quy, T.N.; Minh, T.N.; Van, T.M.; Viet, T.D. Antihyperuricemia, Antioxidant, and Antibacterial Activities of Tridax procumbens L. Foods 2019, 8, 21. [CrossRef]

31. Van, T.M.; Xuan, T.D.; Minh, T.N.; Van Quan, N. Isolation and Purification of Potent Growth Inhibitors from Piper methysticum Root. Molecules 2018, 23, 1907. [CrossRef]

32. Abarca-Vargas, R.; Peña, C.; Petricevich, V.L. Characterization of Chemical Compounds with Antioxidant and Cytotoxic Activities in Bougainvillea x buttiana Holttum and Standl, (var. Rose) Extracts. Antioxidants 2016, 5, 45. [CrossRef]

33. Gonzalez, Y.S.; van der Maden, E.C.L.J. Opportunities for Development of the Moringa Sector in Bangladesh: Desk-Based Review of the Moringa Value Chains in Developing Countries and End-Markets in Europe; Centre for Development Innovation, Wageningen UR: Wageningen, The Netherlands, 2015; pp. 15-102.

34. Otunola, G.; Arise, A.; Sola-Ojo, F.; Nmom, I.; Toye, A. Effect of Addition of Moringa Leaf By-Product (Leaf-Waste) on Proximate and Sensory Characteristics of Cookies. Agrosearch 2013, 13, 69. [CrossRef]

35. Iwansyah, A.C.; Julianti, W.P.; Luthfiyantiq, R. Characterization of Nutrition, Antioxidant Properties, and Toxicity of Physalis angulata L. Plant Extract. Asian J. Pharm. Clin. Res. 2019, 12, 95-99. [CrossRef]

36. AOAC. Official Methods of Analysis. ed. Association of Official Analytical Chemist; Association of Official Analytical Chemist: Arlington, VA, USA, 1990.

37. Waterman, P.G.; Mole, S. Analysis of Phenolic Plant Metabolite; Blackwell Scientific: Oxford, UK, 1994.

38. Adeoye, M.D.; Lawal, A.T.; Azeez, L.A.; Olayiwola, O.A. Effect of Solvent Type on the Yields and Mineral Compositions of the Leaf Extracts of Moringa Oleifera L. Afr. J. Pure Appl. Chem. 2014, 8, 134-146. [CrossRef]

39. Kumoro, A.C.; Hasan, M.; Singh, H. Effects of Solvent Properties on the Soxhlet Extraction of Diterpenoid Lactones from Andrographis Paniculata Leaves. Science 2009, 35, 306-309. [CrossRef]

40. Şevik, H.; Belkayalı, N.; Aktar, G. Change of Chlorophyll Amount in Some Landscape Plants. J. Biotechnol. Sci. 2014, 2, 10-16. [CrossRef] 
41. Triyono, A.; Luthfiyanti, R.; Rahman, T.; Pamungkas, N. The Effects of Solvents and Maltodekstrin on the Characteristics of Physalis angulata L. Leaf Extract. In Proceedings of the International Conference on Natural Products and Bioresourch Sciences IOP Conf. Series: Earth and Environmental Science, Tangerang, Indonesia, 23-24 October 2019; p. 012030.

42. Wan, H.; Yu, C.; Han, Y.; Guo, X.; Luo, L.; Pan, H.; Zheng, T.; Wang, J.; Cheng, T.; Zhang, Q. Determination of Flavonoids and Carotenoids and their Contributions to Various Colors of Rose Cultivars (Rosa spp.). Front. Plant. Sci. 2019, 10, 123. [CrossRef]

43. Mechlouch, R.F.; Ayadi, A.; Thabet, G.; Hannachi, E.O.E.H.; Elfalleh, W. Changes in the Physico-Chemical Properties of Palm Date Using Different Drying Methods. Univ. Bull. 2012, 1, 59-78.

44. Mechlouch, R.F.; Elfalleh, W.; Ziadi, M.; Hannachi, H.; Chwikhi, M.; Ben Aoun, A.; Elakesh, I.; Cheour, F. Effect of Different Drying Methods on the Physico-Chemical Properties of Tomato Variety 'Rio Grande'. Int. J. Food Eng. 2012, 8. [CrossRef]

45. Shanmugavel, G.; Prabakaran, K.; George, B. Evaluation of Phytochemical Constituents of Moringa Oleifera (Lam.) Leaves Collected from Puducherry Region, South India. Int. J. Zool. Appl. Biosci. 2018, 3, 1-8. [CrossRef]

46. Iqbal, S.; Bhanger, M. Effect of Season and Production Location on Antioxidant Activity of Moringa oleifera Leaves Grown in Pakistan. J. Food Compos. Anal. 2006, 19, 544-551. [CrossRef]

47. Sreelatha, S.; Padma, P.R. Antioxidant Activity and Total Phenolic Content of Moringa oleifera Leaves in Two Stages of Maturity. Plant. Foods Hum. Nutr. 2009, 64, 303-311. [CrossRef] [PubMed]

48. Kumar, S.; Pandey, A.K. Chemistry and Biological Activities of Flavonoids: An Overview. Sci. World J. 2013, 2013, 1-16. [CrossRef]

49. Minh, T.N.; Tuyen, P.T.; Khang, D.T.; Quan, N.V.; Ha, P.T.T.; Quan, N.T.; Andriana, Y.; Fan, X.; Van, T.M.; Khanh, T.D.; et al. Potential Use of Plant Waste from the Moth Orchid (Phalaenopsis Sogo Yukidian “V3") as an Antioxidant Source. Foods 2017, 6, 85. [CrossRef]

50. Arslan, D.; Özcan, M.M. Study the Effect of Sun, Oven and Microwave Drying on Quality of Onion Slices. LWT Food Sci. Technol. 2010, 43, 1121-1127. [CrossRef]

51. Leone, A.; Spada, A.; Battezzati, A.; Schiraldi, A.; Aristil, J.; Bertoli, S. Cultivation, Genetic, Ethnopharmacology, Phytochemistry and Pharmacology of Moringa oleifera Leaves: An Overview. Int. J. Mol. Sci. 2015, 16, 12791-12835. [CrossRef]

52. Bello, O.S.; Adegoke, K.A.; Akinyunni, O.O. Preparation and Characterization of a Novel Adsorbent from Moringa oleifera leaf. Appl. Water Sci. 2015, 7, 1295-1305. [CrossRef]

53. Bekçi, Z.; Seki, Y.; Cavas, L. Removal of Malachite Green by Using an Invasive Marine Alga Caulerpa racemosa var. cylindracea. J. Hazard. Mater. 2009, 161, 1454-1460. [CrossRef]

Publisher's Note: MDPI stays neutral with regard to jurisdictional claims in published maps and institutional affiliations.

(C) 2020 by the authors. Licensee MDPI, Basel, Switzerland. This article is an open access article distributed under the terms and conditions of the Creative Commons Attribution (CC BY) license (http://creativecommons.org/licenses/by/4.0/). 